\section{Intelligent natural dump flooding well - Case study from the area of the western Persian/Arabian Gulf and possible application in the Croatian mature oil field Beničanci}

Rudarsko-geološko-naftni zbornik

(The Mining-Geology-Petroleum Engineering Bulletin) UDC: $622.2-032.32$

DOI: $17794 /$ rgn.2020.4.3

Preliminary communication

\author{
Damir Zadravec'; Vladislav Brkić ${ }^{2}$ \\ ${ }^{1}$ Fika Eco d.o.o., A.G. Matoša 1, 10310 Ivanić Grad, Croatia \\ ${ }^{2}$ University of Zagreb, Mining, Geology and Petroleum Engineering Faculty, Pierottijeva 6, 10000 Zagreb, Croatia, \\ https://orcid.org/0000-0003-2075-1832
}

\begin{abstract}
In the process of oil reservoir waterflooding, natural water dump flood technology for reservoir pressure decline prevention is considered as an unconventional but technically less demanding, more economical and safer method in comparison to surface power water injection. With natural dump flood technology, a single well serves as a water producer from a water bearing layer (aquifer) and simultaneously through gravity and the pressure difference between the aquifer and the depleted oil reservoir, it serves as a water injector inside the oil reservoir without expensive and complex injecting water treatment facilities at the surface. With the use of such technology and the running of intelligent well completion, it allows for the permanent monitoring of water production, injection rates and temperature inside the chosen reservoir. In addition, in offshore operations, the use of a subsea wellhead with a mud line suspension system allows for the placing of the injector well at the best predetermined position for water injection in a targeting reservoir and, together with an efficient subsurface acoustic data acquisition system, leads to better reservoir management and well integrity improvement. The overview and critical reflection of the drilling and intelligent completion of a natural dump flooding well for reservoir pressure support in partially depleted oil reservoirs in the Persian/Arabian Gulf has been given, referring to both their preparation and execution phase. The possibility of applying natural water dump flood was also considered in the Croatian onshore Beničanci oil field through a pilot project of water injection into the Be-62 well.
\end{abstract}

\title{
Keywords:
}

natural dump flooding well; intelligent well completion; subsea wellhead; mature oil field; IOR

\section{Introduction}

Currently, major petroleum companies operating in the Persian/Arabian Gulf, regardless of the relative low and fluctuating oil prices, have the intention of increasing their oil production and even doubling it in the next few years. The companies are putting great efforts on reducing the operational cost of the ongoing development projects and they are looking for a proven income by investing in mature oil field revitalization. These projects are undergone by drilling new infill wells, drilling sidetracks from existing wells, workovers with massive matrix acid stimulations, drilling and completion of power water injection wells with surface water treatment facilities and finally the drilling and intelligent completion of subsea natural dump flooding wells. In the planning phase of such demanding projects, companies (engaged in exploration and production) should define the objectives and purposes for particular operations and perform modelling as a base for feasibility studies of particular projects. This paper presents an intelligent

Corresponding author: Vladislav Brkić

vbrkic@rgn.hr well design and the intelligent subsea completion of natural dump flooding wells for maintaining formation pressure in partially depleted hydrocarbon reservoirs with a focus on improving well integrity and efficiency, with consideration given to all technical challenges in their planning and execution phases. Intelligent completions obtain down hole pressure and temperature data in real time to identify problems in the reservoir or wellbore and optimize production without costly well interventions (Al-Kady et al., 2016).

In most reservoirs throughout the early stages of oil production, it was recognized that only a small percentage of the original oil in place (OOIP) had had enough natural driving energy to be recovered in the primary production period (Haiyang et al., 2015). Due to depletion, and when the natural driving mechanisms become insufficient for effective and economical oil production, secondary and tertiary oil recovery methods should be applied in order to increase the overall oil production in selected oil fields. Water flooding is one of the most common secondary oil recovery methods for reservoir pressure support in partially depleted oil and gas fields (Subhi et al., 2011). This method can be used to im- 
prove oil recovery (IOR) above the use of non-stimulated, naturally flowing production wells. The water disposal economics becomes essentially important in the production of oil and gas originating from mature oil and gas fields (Ivšinović, 2017; Patacchini et al., 2018). Technically, it can be performed through the application of two different methods (Kumar et al., 2008):

1. Surface water injection and

2. Natural water dump flood technology.

Additionally, in offshore operations, water injection wells can be completed and secured "dry" or "wet" i.e. at surface production offshore facilities (jackets), or with subsea wellheads. The natural water dump flooding method for reservoir pressure support in partially depleted oil reservoirs is unconventional compared to water injection from the surface, but it is also a less complex and more economical method than surface power water injection (Villarroel et al., 2015). With natural dump flood technology, the same well acts as a water producer from the water bearing layer (aquifer) and water injector inside the oil reservoir, and without complex and expensive water treatment at surface plants and facilities (filtration and bacterial treatment). The water injecting process into a targeting reservoir occurs by controlled natural water flow from the water bearing layer (aquifer) by gravity and the pressure difference between two reservoirs (water producing and partially depleted oil reservoir), simultaneously in the same well. As per historically available data, natural dump flooding technology was successfully applied in the Gudair Oil Field in $\mathrm{Ku}-$ wait, some oil fields in Libya, Bolivia and the Egbema West Oil Field in Nigeria (Olukemi Osharode, 2010). In the Persian/Arabian Gulf, natural dump flooding technology is successfully applied offshore of Qatar (URL1).

Drilling and completion of natural dump flooding wells, especially in an offshore environment can pose many strategic, engineering, well integrity, technical and practical challenges (Abdul-Raheem et al., 2015). From a reservoir management point of view, while determining and choosing a reservoir to be considered as a candidate for water flooding, different reservoir characteristics should be considered: reservoir geometry, fluid properties, reservoir depth, lithology and rock properties, fluid saturation, reservoir uniformity, pay continuity and finally the primary reservoir driving mechanism (Thomas et al., 1989). For many of the oil fields in the Persian/Arabian Gulf, especially in offshore Qatar and Saudi Arabia, the primary reservoir driving mechanisms are gas cap drive and water drive (AI-Siddiqi and Dawe, 1998). Water-drive reservoirs (where oil is produced by water expansion) are not usually considered to be candidates for water flooding (where water is injected) because of the natural ongoing water influx. However, in some instances a natural water drive could be supported by water injection in order to support a higher withdrawal rate, to contribute to better distribution of the injected water volume to different areas of the field, to achieve more uniform areal drainage and to allow for better void age balance and influx volumes. The best candidates for water flooding are reservoirs under solution gas drive mechanisms due to low primary recovery and the potential for substantial additional oil recovery by water injection (Tarek, 2010). In addition, oil wells that produce under gas cap drive, due to high gas cap expansion and pressure depletion and if closed on time to prevent further pressure depletion, may also have significant potential and with proper reservoir management and effort, can be put back into production mode with pressure support by water injection.

By definition, a dump flood operation is injecting water into the recipient reservoir from a water source reservoir by the natural force of gravity and the pressure differential of the two reservoirs using the same well (Mahmoud et al., 2019). Dump-flooding is the method of increasing oil production through improving sweeping efficiency or pressure maintenance similar to the mechanism of water-flooding or water injection.

The main difference between a dump flood and a standard water injection method is in how water is injected. For a standard water injection project, seawater or produced water is used as the source of water. For a standard water injection project, seawater or produced water is used as the source of the water. In a dump-flood project, a water-bearing formation is allowed to crossflow into an oil formation inside the same well without water being brought to the surface and remains at reservoir conditions. The main advantages of dump flooding over water injection is in its simplicity and minimal cost required to initiate the dump flood. Since formation water is used for dump-flood, water compatibility is usually not an issue, hence it does not require any treatment or processing prior to injection inside the formation (Abdulhadi et al., 2019).

\section{Waterflooding consideration}

The principal reason for waterflooding an oil reservoir is to increase the oil-production rate and, ultimately, oil recovery (Willhite, 1986). This is accomplished by "voidage replacement" - the injection of water to increase the reservoir pressure to its initial level and maintain it near that pressure (Rose et al., 1989). Voidage replacement refers to replacing the volume of oil, gas and water produced from the reservoir by injected fluids. The voidage replacement ratio is the ratio of reservoir barrels of injected fluid to reservoir barrels of produced fluid (Kim et al., 2019).

Very early on, it was recognized that in most reservoirs, only a small percentage of the original oil in place (OOIP) was being recovered during the primary-production period because of the depletion of the reservoirs' natural energy (Craig, 1993). Dump-flooding was one of the most cost-effective methods to maximize reservoir oil recovery. It is simple because it only requires a 
zone change or an additional perforation to initiate. Compared to a water injection project, it is significantly more cost-effective, requiring minimal investment. One of the main limitations of dump-flooding is that the injection rate and injection pressure is uncontrolled and limited to the pressure difference between the waterbearing formation and the oil formation. This pressure difference will also decrease with time as the waterbearing formation is depleted or as the oil formation pressures increase (Abdulhadi et al., 2019).

Since the early 1970's and due to a rapid decline in reservoir pressure, a peripheral waterflood scheme with dump flooding wells was investigated in several oil fields across the western coast of the Persian/Arabian Gulf, concerning overlaying water bearing layers (aquifers) as a water source for injection placement in dolomite and limestone oil reservoirs (AI-Siddiqi and Dawe, 1998). Simulation studies have shown a significant amount of bypassed oil on the margin of the reservoirs due to uncertainties in old completion designs and well integrity problems of the existing dump flooding wells, which caused a significant reduction of projected and planned water injecting volumes in selected partially depleted oil fields (AI-Siddiqi and Dawe, 1998). The volume of water dumped into selected reservoirs has been monitored over several years through the execution of production logging campaigns (PLC) which ran at an average of every 3 - 4 years per well. In more recent years, these logs have been compromised by seawater inflow during the course of logging operations due to significant reservoir depletion, lack of well pressure control equipment at subsea and subsurface environments, and due to disturbed well integrity. Total pore content replacement with present reservoir pressure depletion in selected oil fields hasn't been achieved over the life of the fields and new studies and reservoir modelling have been carried out to provide information about the feasibility of drilling new natural dump flooding wells or recomplete existing wells to meet production requirements, as well as voidage replacement ratios and to improve well integrity (URL1, page 52 Offshore fields).

\subsection{Well integrity and waterflood contribution evaluation, general engineering background and data based on case study assumptions}

According to annual reports, and data published on internet pages (URL1, page 52 Offshore fields), reservoir economic studies were carried out to evaluate the contribution of every single existing dump flooding well in the peripheral waterflood scheme at selected oil fields (consisting of a series of heterogeneous carbonate reservoirs). Production logging data taken from existing dump flooding wells during the early Production Logging Tool phase (PLT) in the 1980's, before corrosion took place and tools could log an intake profile, shows a significant direct and indirect contribution in the support of several producer zones of selected oil reservoirs (AISiddiqi and Dawe, 1998).

The experience of the first author who worked on a project in the Persian/Arabian Gulf showed casing damage on well-X due to high corrosion in the casing or liner, causing well integrity issues, resulting in the logging tools not being able to even access the target reservoir depth. In addition, while several workover operations on existing natural dump flooding wells, corrosion logs EMIT \& PMIT (URL2) were run and showed significant casing damage in casing strings, especially at aquifer depths because a reaction between the casing and the saline water caused corrosion. Furthermore, casings were not cemented to the surface and a decision was made to abandon the well- $X$ for integrity reasons. Therefore, it was decided to drill well-Y as a replacement of well-X.

At the general dump flooding well which was presented in this paper, as an example for the replacement of an old completion design with new "Intelligent well completion", Gamma Ray (GR) was used for the measurement of radioactivity as a common method.

It was obvious that disturbed well integrity appeared with high corrosion and the destruction of the casing and liner (if it was installed) due to long time exposure to different fluid phases in the wellbore life. The wall thickness of the casing has reduced across the oil reservoirs and presents a high risk of eventual casing breakage and flowing of high-pressure oil into the aquifers. This may result in serious health, safety and environmental (HSE) issues. In addition, since logging tools were stopped at held up depths above targeted reservoirs, the intake profile was never logged to determine the distribution and the received quantity of dumped water per layers of targeted reservoir. For all the aforementioned reasons, most of the wells should be abandoned due to disturbed well integrity and replaced with new ones to maintain pressure and enable controlled water intake in particular areas of the hydrocarbon fields. This could be a very good opportunity for the optimization of perforation intervals across aquifers and targeting reservoirs and particular injectivity tests should be carried out in order to actualize an optimal water dump design. Reservoir quality, lithology and gas saturation in oil reservoirs $\mathrm{C} 1, \mathrm{C} 2$ and $\mathrm{C} 3$ placed in the Persian/Arabian Gulf (composed of fine dolomite and limestone) are expected to be similar to those encountered in future abandoned wells. However, the water saturation across depleted oil reservoirs will be altered as a result of continuous water dumpage. Additionally, induction logs should be kept in targeting reservoirs to determine an accurate measurement of the remaining oil saturation and to improve the reservoir fluid resistivity measurement which may be corrupted by previously dumped saline water from the aquifer. Finally, MDT logs (Modular formation Dynamics Tester) are required to be taken across entire reservoirs in order to 
Table 1: Generalized stratigraphic column for analysed dump flooder well (aquifers and oil reservoirs)

\begin{tabular}{|l|l|c|c|l|l|}
\hline Reservoir unit & Geological age & $\begin{array}{c}\text { Average depth } \\
(\mathbf{m})\end{array}$ & $\begin{array}{c}\text { Average effective thickness } \\
(\mathbf{m})\end{array}$ & Lithology & Pay zone \\
\hline Aquifer A & Late Cretaceous & 1900 & 150 & Chalky limestone & Water \\
\hline Aquifer B & Late Cretaceous & 2100 & 100 & Chalky limestone & Water \\
\hline Oil Reservoir C1 & Upper Jurassic & 2400 & 10 & Dolomite/limestone & Oil \\
\hline Oil Reservoir C2 & Upper Jurassic & 2415 & 5 & Dolomite/limestone & Oil \\
\hline Oil Reservoir C3 & Upper Jurassic & 2430 & 10 & Dolomite/limestone & Oil \\
\hline
\end{tabular}

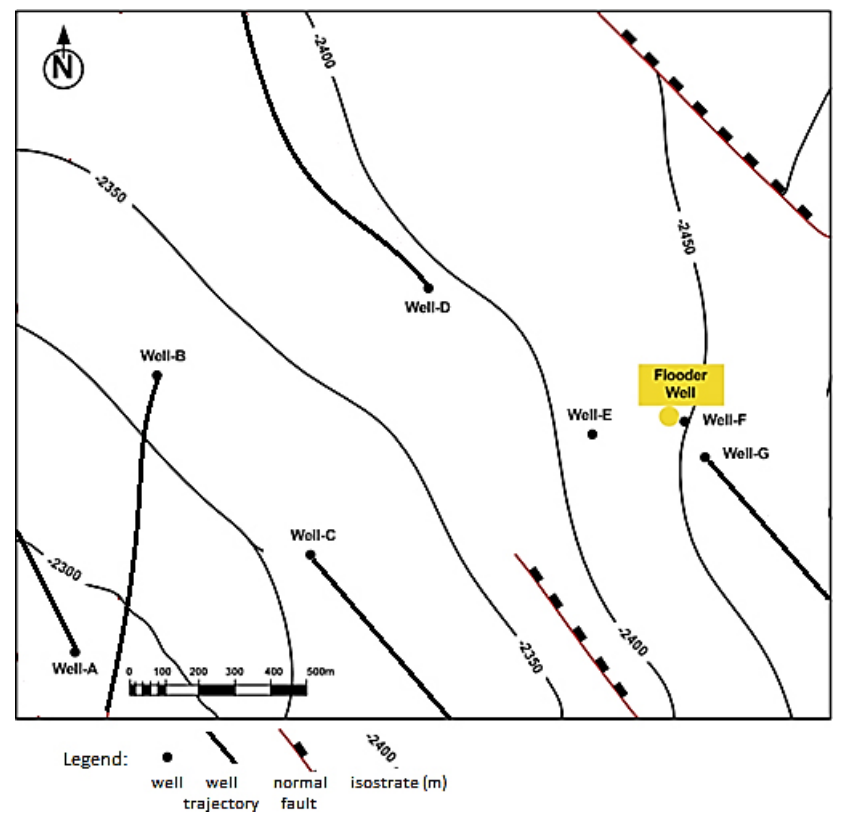

Figure 1: Schematic top structure map of water-flooded reservoir

get static reservoir pressure per layer before running intelligent completion. Table 1 shows a generalized stratigraphic column for an analysed dump flooder well placed in the Persian/Arabian Gulf. The A and B reservoirs represent aquifers (chalky limestone in this case study) while C1, C2 and C3 oil reservoirs (dolomite and limestone in this case study) are used for dump flooding. Figure 1 shows a schematic top structure map for the analysed dump flooder well area.

\subsection{Reservoir economics and operating data}

In the preparation phase for a new drilling and completion campaign of natural dump flooding projects, several important initial conditions should be evaluated, and their requirements need to be satisfied prior to the operations. If any of those cannot be satisfied, projects might be rejected. Generally, the presence of a strong and large aquifer overlaying a partially depleted oil reservoir (see Figure 2) is of the upmost importance. As already discussed in the introduction, this model assumed several existing dump flooding wells in the margins of the partially depleted oil fields, such as in the example in the southwestern part of the Persian/Arabian Gulf, many of which were temporarily abandoned due to well integrity issues. The drilling of new wells could be proposed based on results obtained with an intelligent well design.

In a particular general case presented in this article, if only one dump flooding well is not in function, the cumulative oil production lost in the selected oil field will be significant, and it can be measured in thousands of $\mathrm{m}^{3}$ of oil based on the first author's field experience. Abandonment of the mentioned (corroded) well will generate an immediate decrease of reservoir pressure after the 1 st day of stop dumping water and replacement with a new injection well is mandatory.

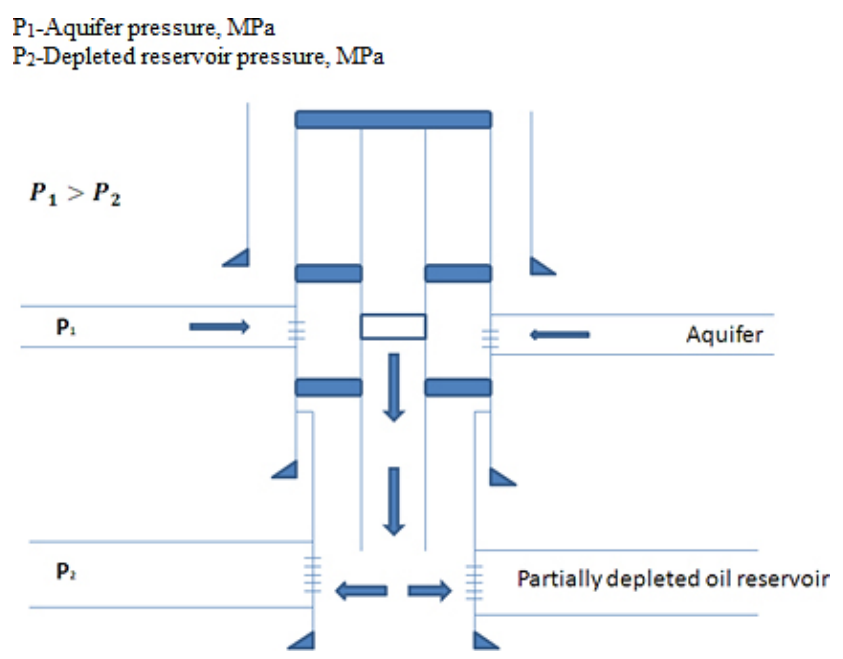

Figure 2: Natural dump flooder intelligent well principle (original work)

\subsection{Drilling and completion phase}

In order to improve well integrity, well control, water injection and operational safety, the main objectives for the new intelligent completion design are to increase data accuracy and provide continuous monitoring of the flow rate, pressure and temperature fluctuations. The new proposed completion design is considered for offshore vertical subsea dump flooding wells in operating environments as shown in Table 2. Such wells could be replacements for any permanently abandoned ones due to well integrity problems based on new evaluations and taking into consideration casing size and water dumping rates, the plan is to complete every single well with $0.114 \mathrm{~m}\left(4 \frac{1}{2}\right.$ ") instead of $0.089 \mathrm{~m}$ ( $3 \frac{1 / 2}{2}$ ") tubing like in abandoned wells to enlarge the water injection flow area. 
Table 2: Average subsea dump flooder well operating data placed in the Persian/Arabian Gulf

\begin{tabular}{|l|l|l|}
\hline Item & Unit & Average \\
\hline Aquifers pressure & $\mathrm{MPa}$ & 25 \\
\hline Depleted oil reservoir pressure & $\mathrm{MPa}$ & 20 \\
\hline Temperature & ${ }^{\circ} \mathrm{C}$ & 100 \\
\hline Water Salinity (aquifers) & $\mathrm{mg} / 1$ & 250000 \\
\hline
\end{tabular}

Completion design (except casing and tubing) incorporates the following main important elements:

- a permanent packer between targetting partially depleted oil reservoirs and aquifers and, retrievable packers between aquifers and wellhead improve reliability and well control;

- down hole inverted venturi fullbore flowmeter to monitor a daily base water flowrate;

- pressure and temperature sensors to detect any anomaly across the time;

- a sliding sleave to introduce the ability to close the water dumping;

- an acoustic data transmission system to retrieve all data storage at the instruments located at the wellhead.

The average water salinity which was in direct contact with the completion accessories and measured historically from source aquifers overlaying selected oil reservoirs, is $260000 \mathrm{mg} / \mathrm{l}$. All materials used in well completion should be resistant to salinity and satisfy requirements of the operating data specified in Table 3 .

Table 3. Aquifer water composition analysis

\begin{tabular}{|l|l|}
\hline & $\begin{array}{l}\text { Aquifers } \\
\text { A and B }\end{array}$ \\
\hline $\mathrm{Na}^{+}(\mathrm{mg} / \mathrm{l})$ & $70000-75000$ \\
\hline $\mathrm{Ca}^{+}(\mathrm{mg} / \mathrm{l})$ & $15000-20000$ \\
\hline $\mathrm{Mg}^{2+}(\mathrm{mg} / \mathrm{l})$ & $2000-3000$ \\
\hline $\mathrm{Cl}^{-}(\mathrm{mg} / \mathrm{l})$ & 150000 \\
\hline $\mathrm{SO}_{4}^{2-}(\mathrm{mg} / \mathrm{l})$ & $200-400$ \\
\hline $\mathrm{HCO}_{3}^{-}(\mathrm{mg} / \mathrm{l})$ & $100-300$ \\
\hline $\mathrm{pH}^{2} 25^{\circ} \mathrm{C}$ & 6 \\
\hline Density at $90^{\circ} \mathrm{C}(\mathrm{kg} / \mathrm{l})$ & 1.15 \\
\hline Salinity $(\mathrm{mg} \mathrm{NaCl} / \mathrm{l})$ & 250000 \\
\hline
\end{tabular}

\section{Well plan and evaluation requirements}

Chapters 3 and 4 are based on the first author's participation in the natural dump flooder well project- $X$ in the Persian/Arabian Gulf. The new intelligent well was used as a replacement for the old one, and due to well integrity issues, the natural dump flooded well was permanently abandoned, and drilled as per the following sequence: a $0.66 \mathrm{~m}$ (26") section of hole was drilled and $0.51 \mathrm{~m}$ (20") casing equipped with a Landing ring assembly for the Mudline Suspension System (MLS) was run and cemented to the surface. The Mudline Suspension System allowed for a hanging of $\left.0.34 \mathrm{~m} \mathrm{(13}{ }^{3 / 8^{\prime \prime}}\right)$, $0.24 \mathrm{~m}\left(9^{5 / 8^{\prime \prime}}\right)$ casing 4 meters below sea bed level, and subsea riser, tubing spool and X-mas tree installation. A $0.41 \mathrm{~m}$ (16") section of a hole was drilled and a $0.34 \mathrm{~m}$ $\left(13^{3 / 8}\right)$ casing was run and cemented to the hanging depth in the Mudline Suspension System. A $0.31 \mathrm{~m} \mathrm{(12}$ $\left.{ }^{1 / 4}\right)$ section of a hole was drilled and a $\left.0.244 \mathrm{~m} \mathrm{(9}{ }^{5 / 8}\right)$ casing was run and cemented to the hanging depth in the Mudline Suspension System. A $0.21 \mathrm{~m}\left(8^{1 / 2}\right)$ section of a hole was drilled and a $0.18 \mathrm{~m}$ (7') liner was run and cemented.

Besides standard mud logging and sample collection while drilling each section of the well, electrical wire line logging of the $0.21 \mathrm{~m}\left(8^{1 / 2}\right)$ section was required to determine reservoir properties and static pressure by using the following electrical wireline logging tools: PEX (Platform Express ) - HRLA (High-Resolution Laterolog Array) - AIT (Array Induction Imager ) - MDT (Mechanical Downhole Tractor ) - GR (Gamma Ray) (Hill, 1990).

After setting and cementing the $0.18 \mathrm{~m}$ (7') liner, a cement bond evaluation across liner was required by using the following electrical wireline logging tools: $\mathrm{CBL}$ (Cement Bond log) - VDL (Variable Density Log) - GR (Hill, 1990).

The extended leak of test (ELOT) was required to determine the fracturing pressure in the aquifer and the targeting reservoir by two possible options: using the TAM straight J packer or MDT tool using dual packers. ELOT was particularly very important in order to precisely define the fracturing pressure gradient for both the water injector (aquifer) and the injecting reservoir (to verify the injectivity index without fracturing the reservoir).

\section{Running completion, stimulation and testing}

The well was completed with $0.114 \mathrm{~m}$ (4 1/2") intelligent components to enable the measurement of the water dumping rate from the aquifer into the targeting oil reservoir, as well as its dumping pressure and temperature. The main objectives for the new completion design was to improve well control, injection safety and to provide continuous monitoring of the flow rate as well as the pressure and temperature. After drilling operations, perforations and stimulations were done as outlined in the following sections.

\subsection{Perforation and stimulation across oil reservoirs (general)}

The high shot density (HSD) guns with Power Jet Charges should be run on a wireline to perforate selected oil reservoir intervals. After perforating, a scraper was run to scrape the inside of the liner across perforation intervals and the permanent packer setting depth. After 
the scraper run, a straddle packer assembly was run to straddle and allow acid stimulation to clean the compact perforated zone and prepare the perforated interval for the injection test.

\subsection{Injection step rate test}

Several aspects of the design and operations in the execution phase of natural dump flooding wells were critical for their success. The first is that the targeting reservoir was partially depleted and had sufficient injectivity to take the desired volume of dumped water each day. The expected injectivity was calculated on the basis of routine core analysis, special core analysis and/or log data, and from the existing production wells productivity. However, well injectivity tests were carried out in the execution phase by injecting filtrated sea water inside the reservoir as per the above mentioned procedure. The average measured oil reservoirs pressure $\mathrm{P}_{\text {res }}$ for a selected well as shown in Table 2 was $20 \mathrm{MPa}$. Injection pressure as a function of the reservoir pressure gradient and surface injection pressure was $30 \mathrm{MPa}$ (see Equation 1) where $10 \mathrm{MPa}$ wellhead pressure was used as the measured data before injection. Injection pressure must be higher than the reservoir one which enables reservoir water flooding.

$$
P_{i}=P_{r e s}+P_{w h}=20+10=30 M P a
$$

Where:

$P_{i}$ - surface wellhead pressure while injection step rate test, $\mathrm{MPa}$,

$P_{\text {res }}$ - average depleted oil reservoir pressure, $\mathrm{MPa}$,

$P_{\text {wh }}^{\text {res }}$ - used wellhead pressure, MPa.

The maximum injectivity rate depends on the reservoir pressure gradient (mentioned before) and the installed wellhead at the surface, therefore the maximum injection pressure would not exceed fracture gradient and wellhead equipment pressure.

For calculations, the maximum injectivity rate of $2000 \mathrm{~m}^{3} /$ day was used.

Reservoir injectivity index is calculated as follows (see Equation 2):

$$
I_{\text {ind }}=\frac{I_{r}}{P i-P_{\text {res }}}=\frac{2000}{30-20}=\frac{2000}{10}=200 \mathrm{~m}^{3} / \mathrm{d} / \mathrm{MPa}
$$

Where:

$I_{\text {ind }}-$ injectivity index, $\mathrm{m}^{3} /$ day $/ \mathrm{MPa}$,

$I_{r}-$ maximum injectivity rate, $\mathrm{m}^{3} /$ day,

$P_{i}$ - surface wellhead pressure while injection step rate, $\mathrm{MPa}$,

$P_{\text {res }}$ - average reservoir pressure, MPa.

The injectivity index $I_{\text {ind }}$ shows the reservoir pressure increasing by $1 \mathrm{MPa}$ while pumping $200 \mathrm{~m}^{3}$ of sea water per day, where $I_{r}$ was the maximum injection rate of $2000 \mathrm{~m}^{3} /$ day.

\subsection{Perforation and stimulation across aquifers}

A similar procedure performed across partially depleted oil reservoirs was repeated across aquifers before acid stimulation. The $0.114 \mathrm{~m}\left(4^{1 / 2}\right)$ high shot density (HSD) guns was run on wireline to perforate aquifer intervals. After perforating, a scraper was run to scrape the inside of the casing across perforation intervals and a retrievable top packer setting depth. After the scraper run, a packer assembly was run to straddle each of the perforated aquifer intervals and to allow for acid stimulation which needs to be squeezed inside the aquifer perforated interval before the injectivity test. Stimulation care should be taken not to achieve or overlap an aquifer fracturing pressure gradient. After acid stimulation, PLT (Production Log Tools) logs was run to measure waterdumping rates. Once logs were done, an intelligent completion with flow meters and a retrievable packer and permanent packer was run. After the subsea wellhead and X-mas tree installation, PLT logs were run once again to measure the final injection profile and aquifer contribution. The proposed wellhead should be suitable for eventual future power water injection conversion. In addition, the connection should be able to accommodate the running of the rigless Subsea Intervention Device (SID). The wellhead should be deployed with the completion, with wet connectors and data transmission systems already installed. The size and material for downhole mechanical components, such as packers, mandrels and sliding sleeves are designed to increase the reliability of completion. The material selection of carbon steel should meet operating data conditions and should be used for tubing. The sliding sleeve, gauge mandrels and flowmeter used was the Inconel 718 in order to improve the component life span. The downhole electronic components were provided by the same manufacturers as the wellhead and downhole completion mechanical items in order to ensure consistency throughout. Downhole pressure and temperature sensors were rated the same as a wellhead and for the environmental temperature in subsurface. A downhole flow meter showed flow rates, pressure loss across the venture flow meter, permanent system pressure loss, inlet velocity, throat velocity, erosion rates, and associated measurement uncertainty with $100 \%$ water injection. The Data Acquisition Unit and Transmission System consisted of a subsea data logger unit equipped with an acoustic transmission system which was interrogated remotely with a surface transceiver or directly via cable to a standard surface computer. The data logger unit, Sonardyne Acoustic Data Logger (ADL) mounted on the X-mas tree, was powered by an external battery pack suitable for long or short term deployment. It was constructed from super duplex steel. The data logger unit was interrogated via connector with a hard wired umbilical that is either ROV (Remote Operated Vehicle) mutable or connected to a jump cable prior to deployment. The surface transceiver unit 
was water resistant and contained a directional acoustic transducer with the transceiver electronics. It enabled high levels of noise rejection from the rear and side and received acoustic signals effectively in the presence of survey vessels thrusters' noise. The transceiver was typically lowered into the water by a small crane from the surveying vessel. The surface interface unit operated with standard computers interfaced to the transceiver via a Surface Interface Unit and provided a serial communication interface to the transceiver and DC power.

\section{Natural water dump flood in Beničanci mature oil reservoir}

The Beničanci oil field is located in the eastern part of Croatia (see Figure 3). The field was discovered in

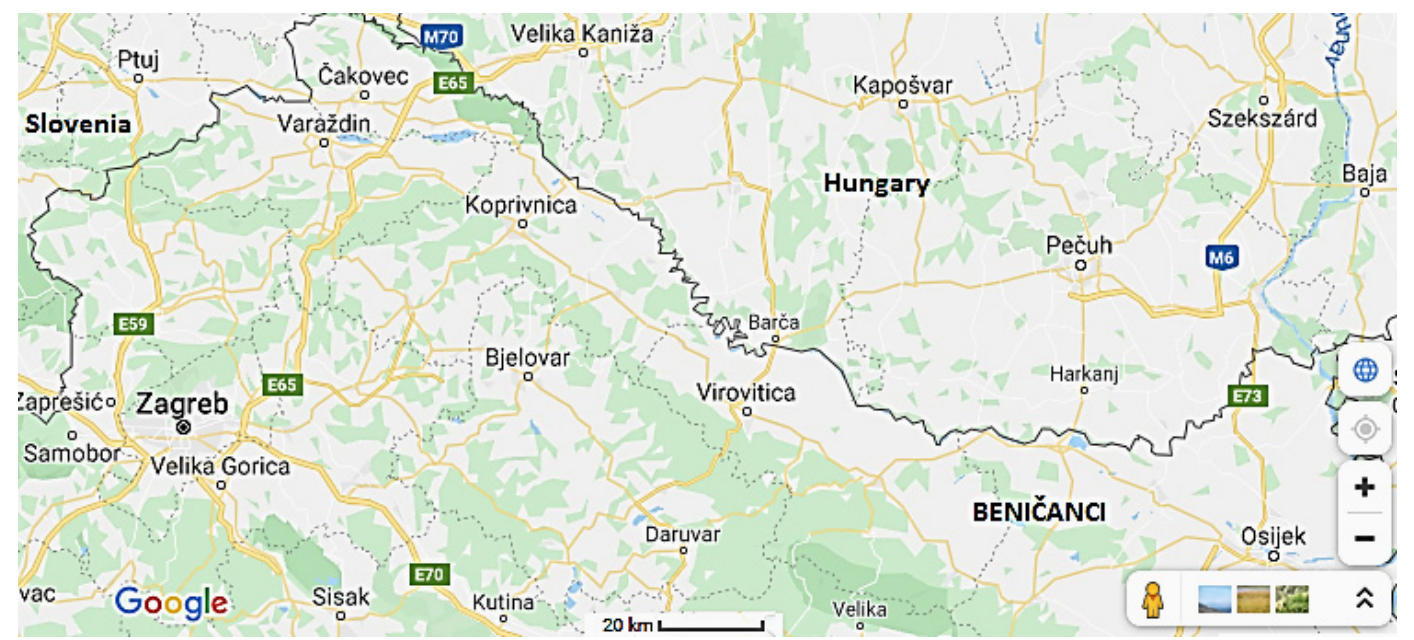

Figure 3: Location map of Beničanci field (URL3)

Table 4: Stratigraphic column drilled by Beničanci-62 well (Brkić, 2011)

\begin{tabular}{|l|l|l|l|l|}
\hline Reservoir units & Geological age & $\begin{array}{l}\text { Depth } \\
(\mathbf{m})\end{array}$ & Lithology & Pay zone \\
\hline Aquifer A & Lower Pontian & $1118-1581$ & Sandstone & Water \\
\hline Aquifer B & Lower Pontian & $1610-1990$ & Sandstone & Water \\
\hline Beničanci mature reservoir & $\begin{array}{l}\text { Lower } \\
\text { Miocene }\end{array}$ & $2113-2227$ & $\begin{array}{l}\text { Limestone-dolomite breccia } \\
\text { (secondary porosity) }\end{array}$ & Oil/water \\
\hline
\end{tabular}

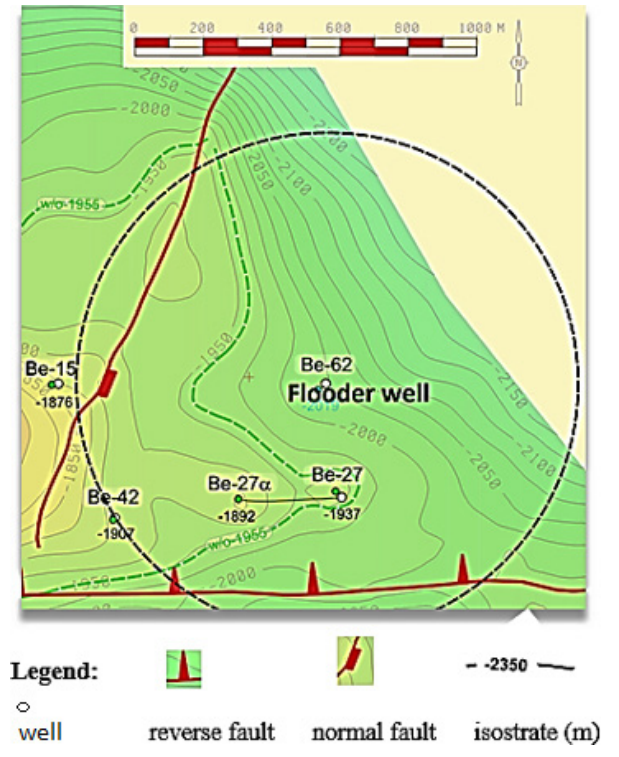

Figure 4: Schematic top structure map of the Beničanci Field in the area of the Be-62 flooder well (Brkić, 2011)
Table 5: Average dump flooder parameters (Brkić, 2011)

\begin{tabular}{|l|l|l|}
\hline Item & Unit & Average \\
\hline Aquifers pressure & $\mathrm{MPa}$ & 20 \\
\hline Mature oil reservoir pressure & $\mathrm{MPa}$ & 18.5 \\
\hline Temperature & ${ }^{\circ} \mathrm{C}$ & 130 \\
\hline Water Salinity (aquifers) & $\mathrm{mg} / \mathrm{l}$ & 15000 \\
\hline
\end{tabular}

1969, and oil production began in 1972. Three years later, waterflooding started by injecting water for additional oil recovery. The Beničanci production reservoir is well developed with moderate deviations in permeability along the interval. The lithological composition is predominantly limestone-dolomite breccia. The reservoir is saturated with oil in the top parts of the structure. Reservoir properties are related to primary and secondary porosity of different genesis and variable values.

The average total porosity is $7 \%$ and the average oil saturation is $71 \%$. The permeability of the reservoir is $0.575 \mu \mathrm{m}^{2}$. The reservoir depth is from $2113 \mathrm{~m}$ to $2227 \mathrm{~m}$ 


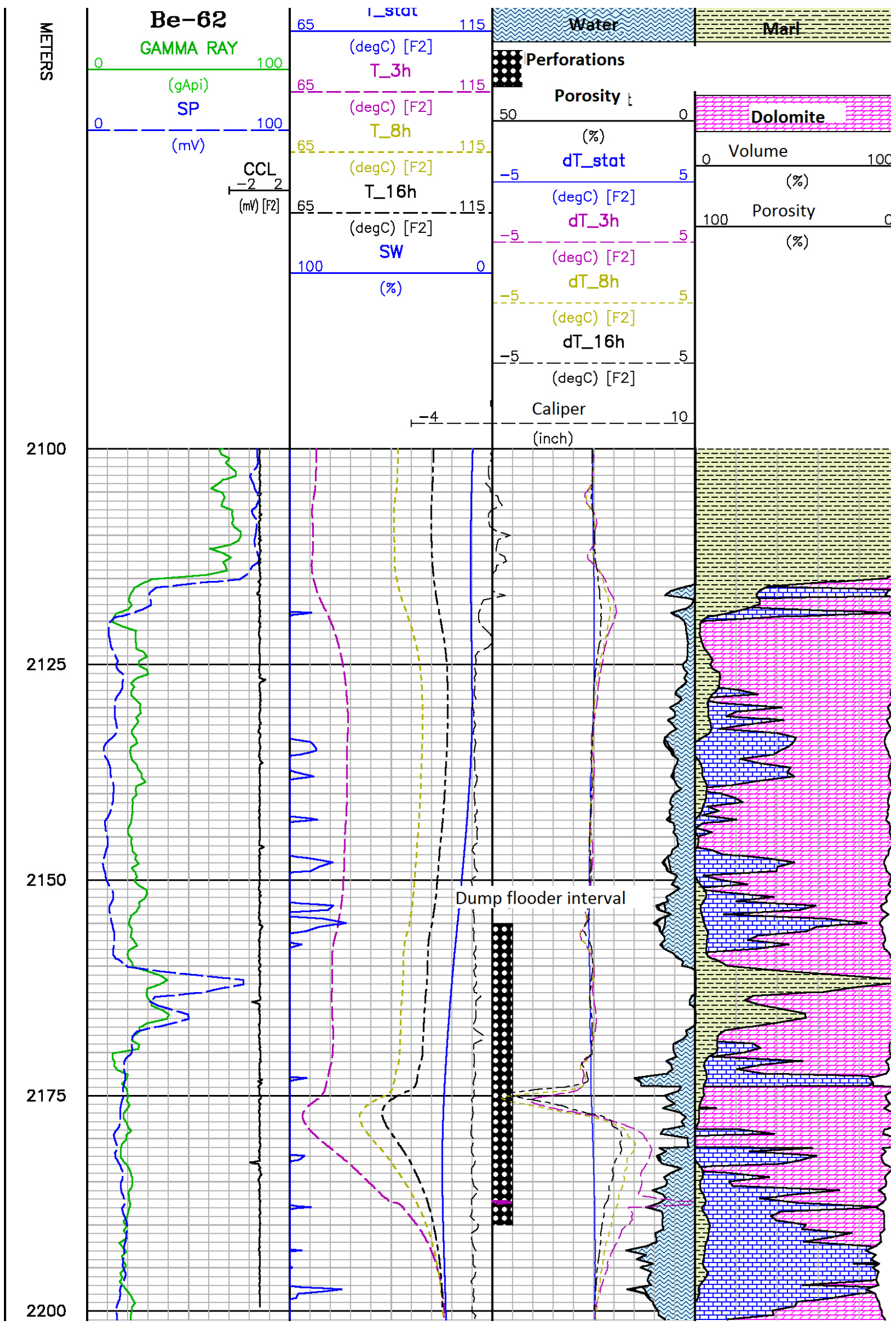

Figure 5: Composite log prior and after water injection into Be-62 well (Brkić, 2011) 
drilled by Beničanci-62 well (of Miocene age). The formation pressure of $18.5 \mathrm{MPa}$ is lower than the hydrostatic one (Brkić, 2011) and it was the main reason for selecting this pilot well as a natural water flood well (aquifer pressure is higher than the oil reservoir pressure).

Sandstone layers called the A series begin at a depth of $1118 \mathrm{~m}$. The sandstone layers are saturated with brackish water. At a depth of $1581 \mathrm{~m}$, marl separates the 12 sandstone formations called series B. This series is also saturated with brackish water. Well logging measurement recognised three intervals for well production (1750-1793m, 1870-1900m and 1923-1960m). The intervals have good permeability because their porosity is from $18 \%$ to $20 \%$ and the average formation pressure is $20 \mathrm{MPa}$ (Brkić, 2011). Sandstone formations marked as series A and B are separated from each other by marls. Therefore, the A and B series of sandstones were used as aquifers $\mathrm{A}$ and $\mathrm{B}$ for the water dump flooding pilot project (see Table 4). The natural dump flooder well principle was the same as the one shown earlier in Figure 2.

Figure 4 shows a schematic top structure map of Beničanci field surrounded by Be-62 flooder well (shown by a circle) while Table 5 shows the mentioned average dump flooder parameters.

Through qualitative interpretation of measured temperature diagrams in static conditions presented by the blue line (see Figure 5) prior to and after water dump flood (3, 8 and 16 hours after water injection presented by the pink, light green and black colored lines), it has been established that the water flowed through the dump flooder interval.

Based on all the geological and production data and a comparison with casy study from the Gulf, it was concluded that this natural water dump technology can be applied to the specific case of the Beničanci mature oil field. This location included the appropriate aquifers and partially depleted oil reservoirs whose pressure was lower than the hydrostatic one and the aquifers' pressure. The mature field Beničanci is still active.

\section{Conclusion}

The most important requirement is the presence of strong (high salinity-more than $10000 \mathrm{mg} / \mathrm{l}$ ) aquifers in areas above the partially depleted reservoir with aquifer pressure being greater than mature reservoir pressure. The targeting reservoir injectivity index should be high enough $\left(200 \mathrm{~m}^{3} / \mathrm{d} / \mathrm{MPa}\right)$ to take the estimated water dumping rates and volume from aquifers in defined boundaries and fracturing pressure limitations. From a reservoir management's point of view, significant oil reserves should be left in the reservoir after primary recovery through natural reservoir energy as to make projects economically feasible. During primary recovery, only a small percentage of the initial hydrocarbons in place are produced, typically around $10 \%$ for oil reservoirs. This should be evaluated as presented through PLT logging and data interpretation. Based on the results of simulations, well construction and proposed completion designs should be issued, resistant on the expected fluid chemistry, physical properties, and expected subsurface pressure distribution. In addition, economical analysis should be done to determine project pay out time through increased oil production.

Natural dump flooding wells, especially in offshore environments are exposed to significant well integrity issues. The presence of different types of fluids in the wellbore, especially water with different chemical compositions and physical properties requires materials and technology to be incorporated into a well design, and during the execution phase which will keep well integrity at a safe technical level according to high safety and environmental requirements. All materials used in well construction and completion should be resistant to aquifer water chemical compositions and satisfy requirements of the subsurface operating data. To improve well integrity, well control and to enable the remote measurement of water production and dumping rates, the most recent well design in offshore environments recommends subsea wellheads with mudline suspension systems and intelligent well completion accessories. The proposed well design and waterflooding method has significant advantages in comparison to conventional completion and power water injection methods from surface water injection facilities. A subsea natural dump flooding well has the possibility to dump water exactly at predetermined areas, as per reservoir areal distribution most suitable for water injection. With the use of natural dump flooding technology, there are significant reductions in costs for surface power water injection facilities (jacket, water treatment plant, compressors). The proposed intelligent well completion allows for the remote monitoring of water dumping rates, pressure and temperature distribution across the well bore, and this helps to improve reservoir management. Recommended modern acoustic data transmission systems allow for the retrieval of all data storage at the instruments located at the wellhead and this helps operators to minimize the fluid losses, improve reservoir management, maintain well integrity, and optimise waterflooding process. Technology with natural dump flooding wells for reservoir pressure support in partially depleted oil reservoirs is an universal method and with fulfilling predetermined reservoir, well integrity and HSE requirements, it can be applied widely in the oil industry in both the onshore (for example water injection pilot project on Beničanci mature oil field, Croatia) and offshore environment (mentioned case study in Arabian/Persian Gulf). Successful aplication of the presented technology showed a possibility for a significant pressure increase in a partially depleted oil reservoir which QP achieved on their offshore fields in predetermined boundary conditions.

Dump flooding is one of the most cost-effective IOR method. It requires a simple activity to initiate, such as 
zone change or additional perforation. Compared to a water injection project, it is significantly more cost-effective, requiring minimal investment (compressors or water treatment plants are not required).

\section{Acknowledgement}

The case study is owned by Quatar Petroleum Company where the first author worked several years ago. The authors have permission only for the use and publication of the general reservoir data.

\section{References}

Abdulhadi, M., Tran, T., Chin, H.V., Suggust, A.A., Usop, M. Z., Zamzuri, D., Dolah,K. A., Abdussalam, K., Munandai, H., Yusop, Z. (2019): A Value Driven Approach for Implementing a Simple and Low-Cost Natural Dump-Flood in an Offshore Environment: Lessons Learned from the First Successful Natural Dump-Flood in Malaysia. Paper SPE 194659-MS, 13 pages, SPE Oil and Gas India Conference and Exhibition, Mumbai, India, 9-11 April 2019, Society of Petroleum Engineers

Al-Kady, M., Omar A., Ginawi, I., Bahgat, A., Abdelmotaal, H., Botros, K. (2016): Improved field recovery and drilling costs in Agiba using ESP reversed Y-tool dump-flood solution. Paper SPE-181540-MS, 12 pages, SPE Annual Technical Conference and Exhibition, 26-28 September, Dubai, UAE, Society of Petroleum Engineers

Abdul-Raheem, M., Chetri, H., Al-Towaitan, T., Badusha, S.I. (2015): A paradigm change in water flood strategy using horizontal injectors in the Sabriyah field. North Kuwait. Paper SPE 172612-MS, 17 pages, SPE Middle East Oil \& Gas Show and Conference, 8-11 March, Manama, Bahrain, Society of Petroleum Engineers

AI-Siddiqi, A., Dawe.R, A (1998): A review of petroleum engineering aspects of Qatar's oil and gas. Engineering Journal of the University of Qatar, 11, $11-45$.

Brkić, V. (2011): The assessment of economic impacts of petroleum industry waste injection into appropriate formations compare with another methods of waste disposal. Doctoral thesis, University of Zagreb, Faculty of mininggeology and petroleum engineering

Craig, Jr. F. F. (1993): The Reservoir Engineering Aspects of Waterflooding. SPE Monograph Series Vol. 3, Society of Petroleum Engineers

Haiyang, S., Longxin M., Haiying H., Yongge L., Bo L. (2015): Development mechanisms and influencing factors of dump flooding. Petroleum Exploration and Development, 42, 5, 691-696.

Hill, A.D. (1990): Production logging-theoretical and interpretive elements. SPE Monographs series, Volume 14

Ivšinović, J. (2017): The analysis of water injection systems in sandstone hydrocarbon reservoirs, case study from the western part of the Sava depression. Rudarsko-geološkonaftni zbornik (The Mining-Geology-Petroleum Engineering Bulletin), 32, 1, 17-24
Kim, T.W., Vittoratos, E., Kovscek, A.R. (2019): Recovery efficiency of a $28^{\circ} \mathrm{API}$ crude-oil system as a function of voidage replacement ratio. Journal of Petroleum Science and Engineering, Volume 175, 1063-1087

Kumar, M., Hoang, V. T., Satik, C., \& Rojas, D. H. (2008): High-Mobility-Ratio Waterflood Performance Prediction: Challenges and New Insights. SPE Reservoir Evaluation and Engineering Journal, 307-622.

Mahmoud, A., Khayami, A., Mansoor, M., Buasali, M. (2019): Integrated Reservoir Study to Maximize Oil Recovery by Optimizing Shuaiba Dump Flooding into the Kharaib Reservoir. Abu Dhabi International Petroleum Exhibition \& Conference, Abu Dhabi, UAE, 11-14 November 2019, Society of Petroleum Engineers

Olukemi Osharode, C. (2010): Application of natural water dump-flood in a depleted reservoir for oil and gas recovery - Egbema West example. Paper SPE 140634-MS, 7 pages, Nigeria Annual International Conference and Exhibition, 31 July - 7 August, Tinapa - Calabar, Nigeria, Society of Petroleum Engineers

Patacchini, L., Ouzzane, D., Draoui, E. (2018): SpreadsheetDriven Real-Time Optimization of the Water-Injection System in a Giant Offshore Field. SPE Production and Operations Journal, 33, 3, 607-622

Rose, S.C., Buckwalter, J.F., Woodhall, R.J. (1989): The Design Engineering Aspects of Waterflooding. SPE Monograph Series Vol. 11, Society of Petroleum Engineers

Subhi H., Rashidi, A., Dey A., Salmi F., Aisary M., (2011): Enhancement of oil recovery through "Dump-flood" water injection concept in satellite field. Paper SPE 142361-MS, SPE Conference Paper, 6 pages, SPE Middle East Oil and Gas Show and Conference held in Manama, Bahrain, 2528 September, Society of Petroleum Engineers

Tarek, A. (2006): Reservoir engineering handbook. Chapter 14. Principles of Waterflooding, 909-1095, Elsevier, Gulf Professional Publishing

Thomas, C. E., Mahoney, C. F., Winter, G. W. (1987): Petroleum engineering handbook. Chapter 44 . Water injection pressure maintance and waterflood process, 1-52, Society of Petroleum Engineers

Villarroel, A.J., Nieto Mino, M.D., Estrella, K.I., Perez, J.A. (2015): Methodology of feasibility study on pilot test for dump flood comletion system. Paper SPE 177039-MS, 27 pages, SPE Latin American and Caribbean Petroleum Engineering Conference, 18-20 November, Quito, Ecuador, Society of Petroleum Engineers

Willhite, G.P. (1986): Waterflooding. SPE Textbook Series, Vol. 3, Society of Petroleum Engineers

\section{Internet Sources}

URL1:http://www.qp.com.qa/en/MediaCentre/Documents/ 2014\%20Annual\%20Report\%20-\%20English.pdf, 2014, page 52 (accessed $1^{\text {st }}$ July 2019)

URL2: https://www.slb.com/-/media/files/production/product -sheet/ps-platform-multifinger-imaging-tool-ps.ashx, 2017 (accessed 1 $1^{\text {st }}$ July 2019)

URL3: https://www.google.hr/maps (accessed 31st July 2020) 


\title{
SAŽETAK
}

\section{Inteligentne bušotine za prirodno zavodnjavanje ležišta - primjer iz Perzijskoga zaljeva i primjena na visoko iscrpljenome hrvatskom naftnom polju Beničanci}

\begin{abstract}
U postupku zavodnjavanja ležišta nafte radi podržavanja tlaka prirodno zavodnjavanje ležišta smatra se nekonvencionalnim, ali zato tehnički manje zahtjevnim, ekonomičnijim i sigurnijim u usporedbi s metodom utiskivanja vode s površine. Tehnologija prirodnoga zavodnjavanja podrazumijeva upotrebu iste bušotine za proizvodnju vode iz vodonosnoga sloja te simultano, s pomoću djelovanja gravitacije i razlike slojnih tlakova u vodonosnome sloju i djelomično iscrpljenome naftnom ležištu, utiskivanje vode u naftno ležište bez izgradnje skupih i kompleksnih površinskih sustava za utiskivanje. Primjenom najsuvremenije tehnologije i vođenjem tzv. inteligentnoga opremanja bušotine omogućeno je stalno praćenje proizvodnje vode, kapaciteta utiskivanja i temperature unutar odabranoga ležišta. Osim toga, u odobalnim operacijama korištenje podvodne bušotinske glave sa sustavom za privremeno napuštanje bušotine omogućava najbolji položaj za utiskivanje vode u ležište i zajedno sa sustavom za prikupljanje podataka vodi do boljega upravljanja ležištem i poboljšanja integriteta bušotine na odabranome naftnom polju. U ovome radu dan je pregled i kritički osvrt na bušenje i inteligentno opremanje bušotina prirodnoga zavodnjavanja ležišta u djelomično iscrpljenim ležištima nafte u Perzijskome zaljevu, a odnosi se i na fazu pripreme bušotine i na samo izvođenje. Dan je i primjer mogućega korištenja tehnologije prirodnoga zavodnjavanja ležišta na hrvatskome (kopnenom) naftnom polju Beničanci koji je u visokome stupnju iscrpljenosti.
\end{abstract}

\section{Ključne riječi:}

prirodno zavodnjavanje ležišta, opremanje inteligentnih bušotina, podvodna bušotinska glava, visoko iscrpljena naftna polja, IOR

\section{Author's contribution}

Damir Zadravec, Ph.D. in petroleum engineering, graduated at the Faculty of Mining, Geology and Petroleum Engineering, the University of Zagreb, had the initial idea for the paper, collected and interpreted data and wrote the first version of the article. The author directly participated in project preparation and the execution of natural dump flooder wells in the Persian/Arabian Gulf from 2011-2018. Vladislav Brkić Ph.D. in petroleum engineering, Associate Professor at Faculty of Mining, Geology and Petroleum Engineering, the University of Zagreb, interpreted data, reviewed, improved and scientifically edited the paper especially with the possibility of natural dump flooding in the Croatian onshore oil field Beničanci. 